\title{
Indonesian Criminal Politics to Find Illegal Fishing in The Context of The ASEAN Regional Forum (ARF)
}

\author{
Yanti Amelia Lewerissa ${ }^{1}$, Flora. P. Kalalo², Lusy. K.R.F Gerungan ${ }^{3}$, Herlyanty. Y. A. \\ Bawole $^{4}$ \\ \{elyanti_amelia@yahoo.com\} \\ Lecturer at the Faculty of Law, Pattimura University ${ }^{1}$ \\ Lecturer at the Faculty of Law, Sam Ratulangi University ${ }^{234}$
}

\begin{abstract}
The ASEAN Regional Forum (ARF) can be a forum to discuss efforts to tackle illegal fishing that occurs in ASEAN countries, including Indonesia. The purpose of this research is to examine how the role of Indonesia in ARF as a form of Indonesian criminal politics in tackling illegal fishing. The method used in this research is normative legal research using primary, secondary and tertiary legal materials. Methods of data collection are literature study and analyzed qualitatively. Illegal fishing can be done by playing an active role in cooperation between countries in the ASEAN region, such as the existence of ARF, so that it can suppress and even eradicate illegal fishing crimes / crimes that are often committed by fishing vessels from neighboring countries (ASEAN members), due to illegal crimes. Fishing is not only limited to fishing, but there are also other forms of crime such as arms trafficking, narcotics smuggling and human trafficking which can certainly threaten the stability and security of the Indonesian state.
\end{abstract}

Keywords: Political Crime, Illegal Fishing, ASEAN Regional Forum

\section{Introduction}

Indonesia has 16,056 islands that have been named and verified with the most recent Indonesian coastline length of $99,093 \mathrm{~km} 2$, making Indonesia one of the largest archipelagic countries in the world endowed by God Almighty with potential marine resources [1]. For this reason, the potential for marine resources needs to be managed in an integrated manner so that it can be utilized in a sustainable manner. So that it can make Indonesia the world's maritime axis. However, the move to make Indonesia the world's maritime axis is faced with the problem of maintaining maritime security and sovereignty from illegal fishing activities such as IUU Fishing [2].

Illegal, Unreported, Unregulated (IUU) Fishing is a global problem that involves more than one country in its handling. Based on data from the Food and Agriculture Organization (FAO), IUU fishing is estimated to represent $15 \%$ to $30 \%$ of the annual global fish catch. The characteristics of IUU fishing are transnational, and as an area that geographically consists of a large maritime area, Southeast Asia is one of the areas that is vulnerable to IUU fishing [3].

The issue of stability, security and maritime sovereignty from illegal fishing activities is experienced by countries in the Southeast Asia region (ASEAN), including Indonesia. There are several countries in ASEAN that have the potential for abundant fishery resources (such as Indonesia) to become the location for these illegal fisheries, but ironically the illegal fisheries 
themselves come from neighboring countries in the ASEAN region. By paying attention to the impact of IUU fishing on the welfare of a country which causes huge economic losses [4] and the security stability threats it causes, cooperation between ASEAN countries is necessary to eradicate this illegal fishing activity.

Thus, the authors are interested in examining more deeply the role of Indonesia in the ASEAN Regional Forum (ARF) in tackling criminal acts in the capture fisheries sector as a form of Indonesian criminal politics.

\section{Research Methods}

The research method used in this paper is a normative legal research method, namely seeing the law as a norm system [5]. Sources of data used in this study are secondary data consisting of primary, secondary and tertiary legal materials [6]. The technique of collecting data is through literature study and then analysed qualitatively, namely by describing the data in the form of words and used to interpret and interpret the oral or written data from the person or the observed behaviour [7].

\section{Results and Discussion}

\subsection{Results \\ Asean Regional Forum}

The ASEAN Regional Forum (ARF) is a sectoral body under the coordination of the ASEAN Political-Security Community Council. ARF is a forum for dialogue on political and security issues in the Asia Pacific region which was formed to support the process of integration and development of the ASEAN Political and Security Community. ARF participants come from 26 countries and 1 European Union entity (27 in total), consisting of ten ASEAN member countries (Brunei Darussalam, Cambodia, Indonesia, Laos, Myanmar, Malaysia, Philippines, Singapore, Thailand and Viet Nam), ten ASEAN Talk Partners (United States, Australia, Canada, China, India, Japan, New Zealand, Russia, South Korea and the European Union), and 7 other countries in the region (Bangladesh, North Korea, Mongolia, Pakistan, Papua New Guinea, Sri Lanka, Timor Leste). Mention of membership in the ARF was participant [8]. Thus, the ARF, which was formed in 1994, is one of the international organizations that serves as a forum for countries in the ASEAN region and its surroundings to discuss various important issues in the region.

To ensure a broader and more recorded stability in the region, ARF participants discussed extensively not only regional issues, but also international issues of importance to the region. ARF discussed, among others, the political and general security situation of the region, such as the issue of nuclear proliferation, the Korean Peninsula, the deployment of hand-held and light weapons, missile defence and maritime security. ARF also discusses various non-traditional issues including terrorism and other transnational crimes such as illegal trafficking of drugs and narcotics, illegal human trafficking, smuggling and other nonconventional issues such as disaster management, infectious diseases and so on [9] . ARF as a forum for countries in the ASEAN region to discuss and seek solutions for conventional and non-conventional issues in the region. 
The existence of ARF in essence does not have to be interpreted as a forum that is directly aimed at resolving regional security issues. ARF itself is a forum that is not binding and adheres to the principles of ASEAN, namely non-intervention and respect for the sovereignty of other countries. In accordance with the purpose of its formation, ARF aims more at building constructive dialogue among its member countries, so that regional stability is maintained. On the one hand, these principles are the main factors that have slowed down efforts to resolve security issues in the region through the ARF framework. However, on the other hand, these principles are recognized as having succeeded in maintaining peace and stability among Southeast Asian countries, as well as for countries that are members of the ARF. [10]. The existence of the ARF should be a tool / forum for discussion of important issues in the region while still paying attention to the basic principles of ASEAN.

\section{Criminal Politics (Crime Management Policy)}

Sudarto put forward three meanings of criminal policy, namely: in a narrow sense, the overall principles and methods that form the basis of reactions to violations of the law in the form of crimes. In a broad sense, the overall function of the law enforcement apparatus, including the workings of the courts and the police. In its broadest sense, the entire policy taken through legislation and official bodies which aims to uphold central norms in society. On another occasion, Sudarto argued that criminal policy is a rational attempt by society to tackle crime [11].

This is in accordance with Marc Ancel's statement that criminal policy is the rational organization of the control of crime by society [12]. The same thing is also expressed by G. Peter Hoefnagels, that criminal policy is the rational organization of the social reaction to crime [13]. Various other definitions were also put forward by G. Peter Hoefnagels, namely; criminal policy is the science of the responses, criminal policy is the science of crime prevention, criminal policy is a policy of designating human behavior as crime, and criminal policy is a rational total of responses to crime. According to G. Peter Hoefnagels, efforts to combat crime can be done by; [14]

a. criminal law application

b. preventiona without punishment

c. influencing views of sociaty on crime and punishment/mass media

Thus, efforts to combat crime can be divided into two, namely through penal measures (criminal law) and through non-penal measures (not using criminal law). Penal measures are applied as a form of repression or eradication (repressive in nature). Meanwhile, non-penal efforts are carried out as a form of prevention or control (preventive in nature).

Efforts to control crime through non-penal means are more of a preventive measure, so the main objective is to address the factors conducive to the occurrence of crime. These conducive factors, among others, focus on social problems or social conditions that directly or indirectly lead to crime. Social conditions or causes which are the causative factors for the crime cannot be resolved only by using penal means because of the limitations of penal means. For that it needs to be integrated with non-penal means. So that non-penal efforts become strategic efforts in the overall criminal policy [15].

In this paper, we focus more on efforts to tackle the crime of IUU fishing by using nonpenal means (not using criminal law), especially by examining the existence of the ASEAN Regional Forum (ARF) as a forum for representatives of countries in the ASEAN region to discuss important issues. which concerns regional stability and security, including the issue of IUU fishing in the ASEAN region. 


\subsection{Discussion \\ Illegal Fishing in the ASEAN Region}

Based on data from the Ministry of Marine Affairs and Fisheries (hereinafter abbreviated as KKP), there are 3 (three) points of location of Indonesian waters that are targeted by foreign fishing vessels (vessels belonging to neighbouring countries), namely: [16]

1. WPP-NRI 711 which covers the Karimata Strait, Natuna Sea and South China, which has fishery potential of 1,119,040 million tons / year. This area is the destination for Thai and Vietnamese fishing vessels to carry out IUU fishing.

2. WPP-NRI 715 which includes Tomini Bay, Maluku Sea, Halmahera Sea, Seram Sea and Berau Bay, which has a fishery potential of 631,704 million tons / year. This area is the destination for Philippine fishing vessels to carry out IUU fishing.

3. WPP-NRI 718 which covers the Aru Sea, Arafura Sea and the East Timor Sea, which has fishery potential of 1,987,261 million tons / year. This area is the destination for Chinese and Thai fishing vessels to carry out IUU fishing.

The potential fishery resources around the Natuna Sea make it the destination for IUU fishing for Thai and Vietnamese fishing vessels. These foreign ships entered the Natuna sea area repeatedly and this illegal fishing activity was discovered by local fishermen. Even local fishermen believe that law enforcement officers are aware of the illegal fishing action around the Natuna Sea area. As happened on March 1, 2020, the arrest of a number of Vietnamese fishing boats while fishing illegally in the North Natuna Sea in the southwest of the Natuna Islands bordering the South China Sea. The success of operations carried out by patrol boats belonging to the Directorate General of Supervision of Marine and Fisheries Resources (hereinafter abbreviated to PSDKP), the KKP shows the government's commitment to continue fighting illegal fishing activities in the North Natuna Sea [17].

Likewise, with the Arafura Sea which has abundant marine wealth, making the Arafura Sea a very busy waters traversed by foreign-flag fishing vessels which are commonly abbreviated as Foreign Fishing Vessels (KIA) or Indonesian-flagged fishing vessels or commonly abbreviated as Indonesian Fishing Vessels (KII) to catch fish both legally and illegally. IUU fishing practices (illegal, unreported, unregulated) Fishing in the Arafura Sea has been going on since 1976.

The number of illegal fishing in the Arafura Sea is still quite high. Studies on IUU fisheries in Arafura conducted by the Capture Fisheries Research Center (PRPT) DKP in collaboration with the Food and Agriculture Organization (FAO) in 2007-2008 show that in the 2001-2005 period, around 1.258 million tons of fish per year were lost due to IUU practices. . This figure is still open to the possibility of increasing considering that illegal fishing activities in the Arafura Sea have continued since 1976 until now [18].

Based on the results of the analysis and evaluation (ANEV), there are ex-foreign fishing vessels. found 1,132 ex-foreign ships. Ex-foreign fishing vessels spread in several provinces in Indonesia. What is more in Maluku, namely \pm 240 vessels, which are dominated by fishing vessels from China and Thailand. Violations that are often carried out include about $95 \%$ of these ships employing foreign skippers and crew, VMS is not activated, using illegal fuel, double flagging and human trafficking and forced labor (the Benjina case). Meanwhile, the small number of ex-foreign fishing vessels is in the Riau Islands, which is \pm 60 vessels which are dominated by fishing vessels from Thailand. The violations that are often committed by these ex-foreign ships are unknown ship position, double flagging, inactivated VMS and fictitious legal entity.

As a whole, the percentage of vessels is dominated by fishing vessels from China (33\%) and Thailand $(25 \%)$. Task Force 511 also collaborates with state partners and international 
organizations such as Norway, Papua Nuigini, Timor Leste, New Zealand and Australia. to exchange intelligence information regarding foreign ships entering Indonesian waters as well as those leaving Indonesian waters carrying IUU fishing results by utilizing border waters [19].

\section{Indonesian Criminal Politics in Combating Illegal Fishing through ARF}

The existence of the oceans for Indonesia can be described in the four vital functions of the sea, namely: the vital function of the sea as a factor of territorial integrity, the vital function of the sea as a means of transportation, the vital function of the sea as a natural resource and the vital function of the sea as defence and security. marine (marine fours) which are not included in the vital category but can contribute foreign exchange for national development [20].

By paying attention to several functions of the sea and the potential of marine resources that Indonesia has as an archipelagic country, it must be able to be managed and utilized optimally in order to create welfare for all Indonesian people. So of course, the sea has an important meaning for the Indonesian people. So, it is not surprising that the development of the marine sector is a prioritized necessity and an increase in infrastructure that can support Indonesia as the world's maritime axis.

However, Indonesia is also faced with the problem of the proliferation of foreign fishing vessels, both small and large, dredging thousands of tons of fish in Indonesian waters. These foreign fishing vessels fish in excess of the stipulated quota, fish in areas that are not allowed, do not properly report fish catches, and do not even have a license to fish. Illegal, unreported and regulated (IUU fishing) fishing activities threaten the sustainability of the marine environment, food resources, security and state sovereignty. Therefore, this needs to be seen as a serious crime.

Vietnam as one of the countries whose fishing vessels often carry out illegal fishing around North Natuna waters. Even though there is a Strategic Partnership between Indonesia and Vietnam. This Strategic Partnership between the two countries, established in 2013 and Vietnam, is the only ASEAN country that has built a strategic partnership with Indonesia. This cooperation has been continued with the preparation of a Strategic Partnership Action Plan. The two countries also agreed on the importance of cooperation in the maritime and fisheries sector in order to eradicate IUU fishing and promote sustainable fisheries management [21]. However, there are still illegal fishing by Vietnamese boats around the waters of North Natuna, and even local fishermen seem to be foreigners in their own waters.

IUU Fishing has become a multisectoral issue. Handling it is not only the matter of the Ministry of Marine Affairs and Fisheries but involves various agencies and stakeholders. Even the Ministry of Foreign Affairs has consistently raised the issue of IUU Fishing in international forums. As attempted by the ASEAN Political and Security Directorate, as the focal point for handling cooperation at the ASEAN Regional Forum (ARF), it also seeks to take advantage of this forum to strengthen cooperation to combat IUU fishing in the region [22].

As a dialogue forum, ARF has an instrumental role in creating and developing transparency, increasing trust and understanding so as to avoid or reduce mutual suspicion and misunderstanding between participating countries. This will further enhance national peace, security and stability. Strengthening regional peace and security will provide a conducive environment that is essential for the success of national development in each participating country. This in turn will encourage community improvement in the region. 
With regard to eradicating IUU fishing in the region, 27 ARF Participants consist of coastal states, port states, and market states, each of which is urgently needed in eradicating IUU Fishing. comprehensively. ARF is basically a forum for dialogue and cooperation. Given that this mechanism does not have binding results, ARF Participants have a more open position in this forum. In this case, ARF is suitable as a forum for raising awareness and testing the water [23].

A number of activities were initiated by Indonesia to discuss in the ARF forum. In 2014, with the preparation of the ARF Work Plan on Maritime Security 2015-2017, Indonesia attempted to build cooperation in handling IUU Fishing in ARF from both a marine environment and maritime security perspective. As an implementation of the Work Plan, Indonesia also proposed 2 related activities to be held in 2016. This Indonesian effort was successfully approved by the passage of the Work Plan at the 22nd Ministerial Meeting of the ARF 2015 in Malaysia. In 2016, in collaboration with the United States and Timor Leste, Indonesia organized 2 implementation projects, namely the ARF Workshop on Improving Fisheries Management in Honolulu in March and the ARF Workshop on IUU Fishing in Bali in April.

As a proposal for the outcome of the two workshops, Indonesia initiated the drafting of the ARF Statement on Cooperation to Prevent, Deter and Eliminate IUU Fishing to be ratified by the ARF foreign ministers at the 23rd ARF Ministerial Meeting in Vientiane, Laos, 26 July 2016. Indonesia initiated drafting in early 2016 and then consulted with the United States and Timor Leste intensively. The next draft is rolled out for further negotiations with all ARF Participants so that it can produce a draft that can be agreed upon and is binding for all ARF participating countries. However, until the 2016 Ministerial Meeting the draft was not approved by the participating countries of the ARF.

Various meetings were held over a period of 2 years (2015-2017), there were several meetings which noted that ARF gave advice, encouragement, and motivation that IUU fishing is a serious challenge and must use a comprehensive and holistic approach [24]. However, until now there has been no agreement between ARF participating countries regarding the draft regulation on IUU Fishing that can bind all ARF participants.

Indonesia continues to negotiate to voice the importance of serious attention to the crimes of IUU Fishing which not only cause economic losses but can also threaten the stability and security of a country. The form of negotiations and building dialogue in international forums involving countries in the ASEAN region such as voicing the eradication of IUU Fishing by formulating a draft that can bind all participating countries in the ARF forum even though in the end there is no agreement, is a form of overcoming crime by using non penal means (not criminal law).

Namely, through dialogue and cooperation to discuss the various causes and consequences behind the occurrence of a crime (in this case IUU Fishing) and how to overcome or prevent the crime. The dialogue and cooperation pursued by the Indonesian government is indeed faced with a big conflict of interest from ARF participating countries, which in fact are national fishing vessels that often carry out IUU fishing in the Indonesian waters. Indonesia has a great job to build cooperation and intense dialogue with Vietnam (Vietnamese fishing vessels that often carry out IUU fishing around North Natuna waters), China and Thailand (Chinese and Thai fishing vessels often do IUU fishing in the vicinity. the Arafura Sea area), the Philippines (Philippine fishing vessels conducting IUU fishing around the Sulawesi region) and other countries so that an agreement to eradicate IUU fishing is binding which binds all countries in the ASEAN region. 


\section{Conclusion}

IUU fishing crime is a challenge for countries in the ASEAN region. The crime of IUU fishing, which is not only limited to theft of fish, but also has an impact on the stability of the security and sovereignty of a country, it is necessary to have seriousness and agreement with ARF participating countries to prevent and eradicate the crime of IUU fishing. To maintain Indonesia's sovereignty but still consider good diplomatic relations between countries in the ASEAN region, Indonesia continues to garner support from ARF participants, direct discussions and encourage the commitment of countries in the region to work together to prevent and eradicate IUU fishing in the ASEAN region.

\section{Suggestions}

There needs to be cooperation and support between countries in the ASEAN region so that an agreement can be created that can bind all countries in tackling IUU fishing crimes that occur around the ASEAN region

\section{References}

[1] Y. A. Lewerissa dkk, Law Enforcement Criminal Acts in Fisheries, Ayer Journal, Volume 27 Nomor 2 Juli 2020

[2] Prata Aditya Putra \& Sri Wahyuningsih Yulianti, Tinjauan Permohonan Kasasi Penuntut Umum Terhadap Putusan Bebas Dalam Perkara Illegal Fishing (Studi Putusan Nomor: 2329 K/PID.SUS/2015), Jurnal Verstek Volume 7 No. 1 Januari-April 2019, Hal 121

[3] Mauly Dini Budiyanti dan Arfin Sudirman, Implementasi RPOA-IUU di Kawasan Asia Tenggara, Jurnal Hubungan Internasional $\square$ Tahun XII, No.2, Juli - Desember 2019

[4] Y. A. Lewerissa, Praktek Illegal Fishing di perairan Maluku Sebagai Bentuk Kejahatan Ekonomi, Jurnal Sasi Volume 16, Nomor 3 Juli- Sep 2010

[5] Mukti Fajar ND dan Yulianto Achmad, Dualisme Penelitian Hukum Normatif dan Hukum Empiris, Pustaka Pelajar, Yogjakarta, 2010, Hal 34.

[6] Soerjono Soekanto, Pengantar Penelitian Hukum, Jakarta: UI Press, 1986, Hal 22

[7] Lexi. J. Moleong, Metode Penelitian Kualitatif, Bandung: Rosyda Karya, 1991, Hal 4

[8] Sekretariat Nasional - ASEAN Indonesia, http://setnas-asean.id/asean-regional-forum-arf, diakses tanggal 4 Maret 2021

[9] Ditpolkom.Bappenas, Politik Luar Negeri Keanggotaan Indonesia dalam Organisasi Internasional ASEAN Refional Forum, ditpolkom.bappenas.go.id, diakses tanggal 4 Maret 2021

[10] Simela Victor Muhammad, Arti Penting Asean Regional Forum Dalam Menjaga Stabilitas Kawasan, Majalah Info Singkat, Hubungan Internasional, Vol. IX, No. 15///Puslit/Agustus/2017

[11] Barda Nawawi Arief, Handout Kebijakan Hukum Pidana, Semarang, Tanpa Tahun, Hal 1-2

[12] Marc Ancel, Social Defence, a Modern Approach to Criminal Problem, Routledge \& Kegan Paul, London, 1965, Hal 208-209

[13] G. Peter Hoefnagels, The Other Side of Criminology, Deventer, Kluwer, Holland, 1973, Hal 57

[14] Ibid, Hal 99-100

[15] Barda Nawawi Arief, Kebijakan Penanggulangan Kejahatan Dengan Hukum Pidana, di muat dalam Masalah-Masalah Hukum, Semarang, Fakultas Hukum UNDIP, No. 2-4 Tahun XII, 1982, hal 6-7

[16] Kementerian Kelautan dan Perikanan Republik Indonesia, Asal KIA ke WPP NRI, kkp.go.id, diakses tanggal 3 Maret 2021

[17] Imam Prakoro,Mendeteksi Aktivitas Perikanan Gelap di Laut Natuna, https://globalfishingwatch.org/transparansi/mendeteksi-aktivitas-perikanan-gelap-di-laut-natunautara/, dikases tanggal 3 Maret 2021

[18] Victor PH Nikijuluw, Blue Water Crime, Pustaka Cidesindo, Jakarta, 2008, Hal 75 
[19] Kementerian Kelautan dan Perikanan, Laut Masa depan Bangsa, Kedaulatan, Keberlanjutan, Kesejahteraan, Penerbit Buku Kompas, 2018, Hal 27

[20] Flora P Kalalo, Implementasi Asas Desentralisasi dalam Pengelolaan Sumber Daya Laut di Indonesia, Jurnal Formas Vol 2, No. 2 Februari 2009, Hal 98-107

[21] Rizki Roza, IUU Fishing Kapal Vietnam di Perairan Natuna, Majalah Info Singkat, Hubungan Internasional, Vol. XI, No.05/I/Puslit/Maret/2019

[22] Risha Jilian Chaniago, Direktorat Politik dan Keamanan ASEAN, Testing The Water Penguatan Kerja Sama Penanganan IUU Fishing Melaui Asean Regional Forum (ARF), Majalah Masyarakat ASEAN, Edisi 14 Desember 2016

[23] Ibid

[24] Jihad Bahari Putri Harun, Peran ASEAN Regional Forum (ARF) dalam Menciptakan Kawasan Bebas Illegal, Unreported and Unregulared (IUU) Fishing di Indonesia Tahun 2015-2017 , JOM FISIP Vol. 7: Edisi II Juli - Desember 2020 